\title{
KONSENTRASI ABU SEKAM PADI TERHADAP KUALITAS MINYAK KOPRA
}

\section{RICE HUSH ASH CONCENTRATION ON COPRA OIL QUALITY}

\author{
Irwan $^{1}$, Nur Alam $^{2}$, Asrawaty $^{1 *}$ \\ ${ }^{1}$ Program Studi Teknologi Hasil Pertanian, Fakultas Pertanian, Universitas Alkhairaat, Jl. Diponegoro, \\ Fakultas Pertanian Universitas Alkhairaat, Palu 94221, Indonesia \\ ${ }^{2}$ Program Studi Agroteknologi Fakultas Pertanian Universitas Tadulako, Jl. Soekano Hatta KM.9, 94118 \\ Palu, Sulawesi Tengah Indonesia
}

\begin{abstract}
ABSTRAK
Penelitian ini bertujuan untuk mengetahui pengaruh konsentrasi penggunaan abu sekam padi terhadap kualitas minyak kopra dan mendapatkan konsentrasi abu sekam padi yang memberikan pengaruh terbaik terhadap kualitas minyak kopra. Penelitian ini dilaksanakan di laboratorium Agroindustri Fakultas Pertanian Universitas Tadulako Palu. Penelitian ini menggunakan Rancangan Acak Lengkap (RAL). Perlakuan yang dicobakan adalah abu sekam padi yang terdiri dari 6 level konsentrasi yaitu $0,5,10,15,20$ dan $25 \%$ (v/v). Setiap perlakuan diulang 3 kali sehingga terdapat 18 unit pengamatan. Parameter yang diamati adalah recovery minyak, kadar air, kadar asam lemak bebas dan derajat kejernihan minyak. Data yang diperoleh dianalisis dengan sidik ragam, bila menunjukkan pengaruh dilanjutkan dengan uji BNJ pada taraf 5\%. Hasil penelitian menunjukkan bahwa perlakuan konsentrasi abu sekam padi memberikan pengaruh yang sangat nyata terhadap recovery, kadar air, kadar asam lemak bebas dan derajat kejernihan minyak kopra. perlakuan konsentrasi abu sekam padi konsentrasi $20 \%$ memberikan pengaruh yang lebih baik terhadap kualitas minyak kopra.
\end{abstract}

Kata kunci: minyak kopra; abu sekam padi; recovery minyak, kadar air, kadar asam lemak bebas, derajat kejernihan minyak

\section{ABSTRACT}

This study aims to determine the effect of the concentration of the use of rice husk ash on the quality of copra oil and obtain the concentration of rice husk ash which has the best influence on the quality of copra oil. This research was carried out in the laboratory of Agro-Industry Faculty of Agriculture, University of Tadulako Palu. This study uses a Completely Randomized Design (CRD). The treatment that was tried was rice husk ash consisting of 6 concentration levels namely 0, 5, 10, 15, 20 and $25 \%(v / v)$. Each treatment was repeated 3 times so that there were 18 observation units. The parameters observed were oil recovery, water content, free fatty acid content and degree of oil clarity. The data obtained were analyzed by variance, when showing the effect continued with the BNJ test at the level of $5 \%$. The results showed that the treatment of rice husk ash concentration had a very significant effect on recovery, moisture content, free fatty acid content and clarity of copra oil. the concentration of rice husk ash concentration of $20 \%$ gives a better influence on the quality of copra oil.

Keywords: Copra oil; rice husk ash; oil recovery; water content; free fatty acid content, degree of clarity of oil

\section{Pendahuluan}

Di Indonesia tanaman kelapa merupakan salah satu komoditi pertanian yang cukup potensial dan memegang peranan penting, baik

\footnotetext{
${ }^{*}$ Penulis Korespondensi.

E-mail: asrawaty@unisapalu.ac.id. HP : 081327226461
}

dari segi nutrisi maupun dari segi ekonomi. Banyak kegunaan yang dapat diperoleh dari tanaman kelapa, salah satu diantaranya dengan mengolah buahnya menjadi minyak. Minyak kelapa termasuk salah satu minyak nabati yang umum digunakan sebagai minyak goreng. Selain itu, minyak ini dapat juga digunakan sebagai bahan baku membuat sabun, margarin, kosmetik, 
obat-obatan dan bahan pangan lainnya (Grimwood, 1975). Minyak yang dihasilkan dari pengolahan buah segar sering disebut minyak kelapa tradisional atau minyak klentik yang disukai konsumen karena mempunyai aroma dan cita rasa yang khas minyak (Karmawati, $d k k$, 1992).

Sedangkan minyak yang dihasilkan dari pengolahan daging kelapa yang dikeringkan kemudian dipres disebut minyak kopra. Melalui cara ini rendemen minyak kelapa yang diperoleh rendah dan biasanya sanitasi pengeringan kopra kurang sehingga kopra dapat ditumbuhi jamur yang mengakibatkan minyak tidak dapat dikonsumsi secara langsung (Widiandani, $d k k$., 2010). kadar air dan kadar asam lemak bebas yang cukup tinggi sehingga daya tahan simpannya relatif sangat singkat sehingga jangkauan pemasarannya terbatas. Disamping itu, warnanya kurang menarik mengurangi minat konsumen untuk mengkonsumsinya. Kadar air dan kadar asam lemak bebas merupakan penyebab kerusakan minyak kelapa. Oleh karena itu perlu upaya penanganan melalui teknik pengolahan untuk mengurangi kadar air, kadar asam lemak bebas dan perbaikan penampakan warna minyak kopra Ketaren, (1986) minyak kelapa yang belum dimurnikan mengandung sejumlah kecil komponen bukan lemak seperti fosfatida, gum, sterol $(0,06-0,08 \%)$, tokoferol $(0,003 \%)$, dan asam lemak bebas $(<5 \%)$ dan sedikit protein dan karoten.

Salah satu cara untuk menangani masalah tersebut di atas adalah melalui pemberian abu sekam padi. Cara ini berpotensi untuk diterapkan di daerah sentra produksi minyak kelapa karena mudah diperoleh, dan tidak membutuhkan biaya serta mampu meningkatkan mutu minyak. Menurut Proctor, Adhikari and Blyholder(1995). Abu sekam padi mampu menyerap pigmen yang potensial dalam pengolahan minyak kopra. Disamping itu secara signifikan dapat mengurangi kadar fosfor minyak dan mampu menyerap asam lemak bebas pada minyak kopra (Proctor, Clark and Parker, 1995). Dewasaini keberadaan abu sekam padi di Indonesia belum mendapatkan perhatian, dan hanya terbatas untuk beberapa keperluan sederhana misalnya untuk abu gosok. Bahkan dibeberapa daerah sekam padi dibuang dan dianggap sebagai bahan yang kurang bermanfaat. Abu sekam padi merupakan bahan yang sangat potensial sebagai bahan penyerap logam berat dalam air. Abu sekam padi dapat digunakan sebagai adsorben karena selain merupakan material berpori juga mempunyai gugus aktif yaitu $\mathrm{Si}-\mathrm{O}-\mathrm{Si}$ dan $\mathrm{Si}-\mathrm{OH}$ (Setyaningtyas, 2005).

Laporan penelitian tentang penggunaan abu sekam padi pada minyak kopra sampai saat ini belum banyak diketahui. Sehingga dilakukan penelitian penggunaan abu sekam padi pada pengolahan minyak kopra, untuk mengetahui pengaruh konsentrasi penggunaaan abu sekam padi terhadap kualitas minyak kopra dan mendapatkan konsentrasi abu sekam padi yang memberikan pengaruh terbaik terhadap kualitas minyak kopra.

\section{Metode Penelitian}

Bahan utama yang digunakan dalam penelitian ini adalah minyak kelapa dari pengepresan kopra yang diperoleh dari Industri Kecil Menengah (IKM) di jalan I Ngusti Ngurarai. Bahan lainnya adalah abu sekam padi, etanol, aseton, natrium hidroksida dan indicator Phenolphtalein.

Peralatan yang digunakan dalam penelitian ini adalah alat pres, sentrifius, timbangan analitik, erlenmeyer,buret, oven, pemanas listrik (hot plate), desikator, cawan, pengaduk magnetic stirrer, gelas piala dan alat-alat yang terbuat dari kaca dan besi yang umum digunakan di dalam Laboratorium Kimia.

\section{Desain Penelitian}

Penelitian ini menggunakan Rancangan Acak Lengkap (RAL) menurut Gomez dan Gomez (1995). Perlakuan yang dicobakan adalah abu sekam padi yang terdiri dari 6 level konsentrasi seperti yang ditunjukkan pada Tabel 3. Setiap perlakuan diulang 3 kali sehingga terdapat 18 unit pengamatan. Data hasil penelitian dianalisis secara statistik dengan menggunakan uji F. Bila perlakuan menunjukkan pengaruh dilanjutkan dengan uji BNJ pada taraf 0,05 .

Tabel 3. Perlakuan Abu Sekam Padi yang Digunakan dalam Penelitian ini

\begin{tabular}{cccc}
\hline Kode Perlakuan & $\begin{array}{c}\text { Minyak } \\
\text { Kopra }(\mathrm{ml})\end{array}$ & $\begin{array}{c}\text { Abu Sekam } \\
\text { Padi }(\mathrm{ml})\end{array}$ & $\begin{array}{c}\text { Konsentrasi } \\
(\% \mathrm{v} / \mathrm{v})\end{array}$ \\
\hline A0 & 100 & 0 & 0 \\
A1 & 95 & 5 & 5 \\
A2 & 90 & 10 & 10 \\
A3 & 85 & 15 & 15 \\
A4 & 80 & 20 & 20 \\
A5 & 75 & 25 & 25 \\
\hline
\end{tabular}

\section{Prosedur Penelitian}

a. Kopra dipres dengan alat pres hingga tekanan maksimum. Minyak yang diperoleh ditampung. 
b. Abu sekam padi diayak dengan menggunakan ayakan 80 mesh. Kemudian dipanaskan dalam oven pada suhu $120^{\circ} \mathrm{C}$ selama 2 jam. Selanjutnya abu sekam padi disimpan dalam wadah tertutup yang kedap udara.

c. Minyak kopra dicampur dengan abu sekam padi seseuai perlakuan.

d. Campuran minyak kopra-abu sekam padi diaduk dengan pengaduk magnetic stirrer selama 1 jam dengan kecepatan300 rpm.

e. Campuran minyak kopra-abu sekam padi disentrifugasi dengan kecepatan $1.000 \mathrm{rpm}$ selama 1 jam untuk memisahkan minyak kopra dari abu sekam padi.

f. Minyak kopra yang diperoleh pada tahap dianalisis untuk mengetahui rendemen, kadar air, asam lemak bebas, dan derajat kejernihan. Bagan alir pelaksanaan penelitan ini ditunjukkan pada Gambar2.

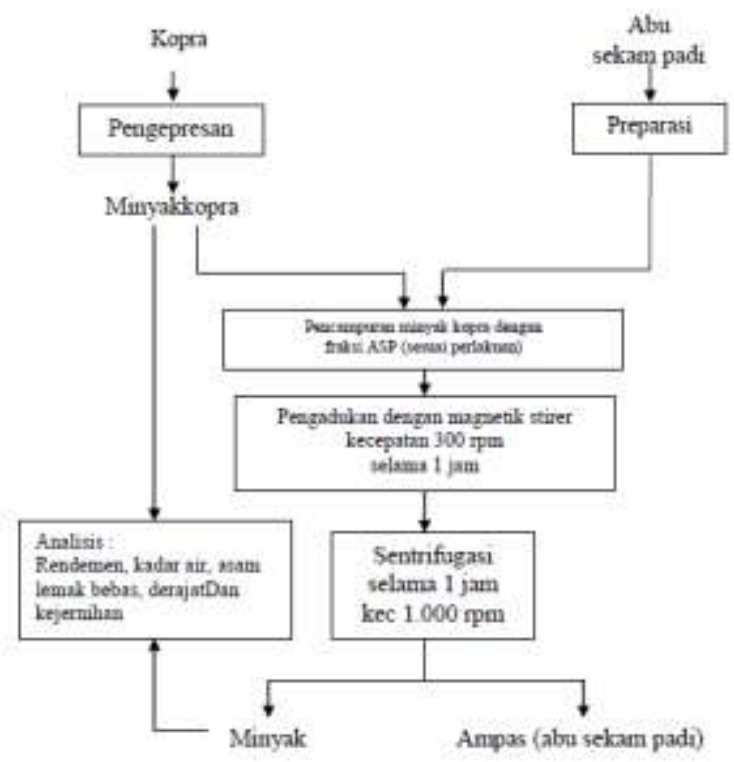

Gambar 1. Bagan Alir Pelaksanaan Penelitian

\section{Variabel Penelitian}

a. Recovery Minyak

Recovery adalah presentase minyak kopra yang diperoleh kembali setelah diperlakukan dengan abu sekam padi.

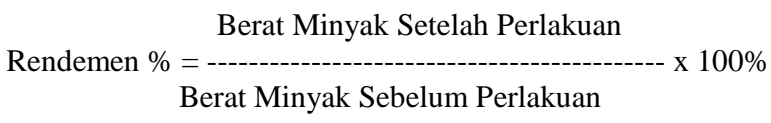

b. Kadar Air Minyak (Apriyantono, $d k k ., 1989$ )

1. Cawan kosong dibersihkan, lalu diberi label kemudian dipanaskan di dalam oven padasuhu $105^{\circ} \mathrm{C}$ selama 15 menit, kemudian ditimbang.
2. Sampel yang telah dihaluskan ditimbang di dalam cawan sebanyak \pm 5 g. Cawan beserta isinya dipanaskan di dalam oven pada suhu $105^{\circ} \mathrm{C}$ selama 2 jam.

3. Dipindahkan ke dalam desikator, lalu didinginkan kemudian ditimbang. Dipanaskan kembali di dalam oven hingga diperoleh berat yang tetap. Nilai kadar air bahan diperoleh melalui persamaan :

$\operatorname{Kadar} \operatorname{Air}(\%)=\frac{(\mathrm{BS}+\mathrm{BCK})-(\mathrm{BC}+\mathrm{I})^{*}}{\mathrm{-a}} \mathrm{\text {BS }}$

Keterangan :

$\begin{array}{ll}\text { BCK } & : \text { Berat cawan kosong } \\ (\mathrm{BC}+\mathrm{I})^{*} & : \begin{array}{l}\text { Berat cawan dengan isi setelah } \\ \text { dipanaskan }\end{array} \\ \mathrm{BS} & : \text { Berat sampel }\end{array}$

c. Kadar asam lemak bebas (Sudarmadji.dkk., 1996).

Sebanyak $\pm 1 \mathrm{~g}$ sampel dimasukkan ke dalam erlenmeyer. Selanjutnya dilarutkan dalam pelarutetanol-aseton 1:1 sebanyak $10 \quad \mathrm{ml}$, ditambahkan indikator phenolphthalein sebanyak 5 tetes, diaduk dengan pengaduk magnetik stirrer selama 30 detik lalu dititrasi dengan larutan $\mathrm{NaOH} 0,01 \mathrm{~N}$. Titrasi dihentikan jika warna larutan berubah menjadi merah muda yang bertahan kurang dari 10 detik. Kadar asam lemak bebas diperoleh melalui persamaan :

Asam lemak bebas $=\frac{\mathrm{V} \times \mathrm{T} \times \mathrm{A}}{\mathrm{m} \times 1000} \times 100 \%$

Keterangan :

$\mathrm{V}$ : Jumlah volume $\mathrm{NaOH}$ yang digunakan untuk titrasi (ml)

$\mathrm{T}$ : Normalitas $\mathrm{NaOH}$

A : Berat molekul asam lemak laurat 205

$\mathrm{m}$ : Berat sampel (gram)

d. Derajat kejernihan

Uji derajat kejernihan minyak dilakukan dengan menggunakan metode spektrofotometer menurut Gwo, et.al. (1985) dalam Sadikin (1992). Sebanyak $1 \mathrm{~g}$ contoh ditimbang ke dalam wadah gelas kemudian diencerkan dengan heksan sampai volume $25 \mathrm{ml}$. Campuran dikocok perlahan sampai larut kemudian diukur transmitannya pada panjang gelombang $330 \mathrm{~nm}$.

\section{Hasil dan Pembahasan}

Recovery minyak (\%)

Analisis ragam menunjukkan bahwa penggunaan abu sekam berpengaruh sangat nyata terhadap recovery minyak kopra. Nilai rata recovery minyak kopra disajikan pada Gambar 2. 
Jurnal Pengolahan Pangan 4 (1) 9-15

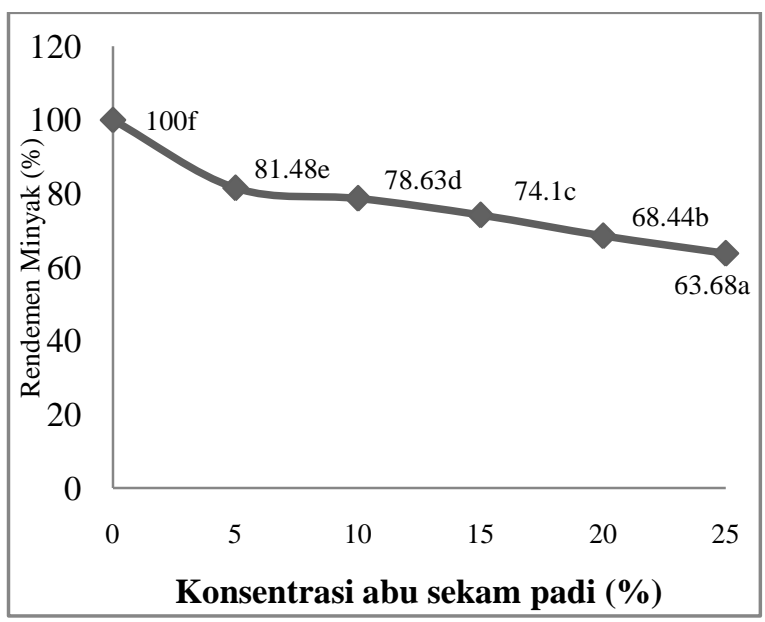

Nilai BNJ 0,05 = 2,19

Gambar 2. Recovery minyak kopra pada berbagai konsentrasi abu sekam padi.

Data yang tersaji pada Gambar 2 menunjukkan bahwa recovery minyak kopra tertinggi $(100 \%)$ ditemukan pada perlakuan control (tanpa perlakuan abu sekam padi), pengaruhnya berbeda nyata dengan perlakuan lainnya. Sebaliknya recovery minyak kopra terendah $(63,68 \%)$ pada perlakuan abu sekam padi konsentrasi $25 \%$, pengaruhnya berbeda nyata dengan perlakuan lainnya. Hasil ini memberi petunjuk bahwa setiap konsentrasi perlakuan abu sekam padi akan memberikan pengaruh yang berbeda terhadap recovery minyak kopra.

Data pada Gambar 3 juga menunjukkan bahwa penambahan jumlah abu sekam padi berbanding terbalik dengan recovery minyak kopra, yaitu recovery minyak kopra menurun dengan meningkatkan konsentrasi abu sekam padi. Hal ini diduga karena abu sekam yang digunakan sebagai absorben/filter selain menyaring kotoran minyak juga menyerap sebagian minyak. Abu sekam bersifat higroskopis yang dapat menyerap air ataupun minyak.

\section{Kadar Air (\%)}

Analisis ragam menunjukkan bahwa penggunaan abu sekam berpengaruh sangat nyata terhadap kadar air minyak kopra. Nilai rata kadar air minyak kopra disajikan pada Gambar 3.

Data yang tersaji pada Gambar 3 menunjukkan bahwa kadar air minyak kopra tertinggi $(0,34 \%)$ ditemukan pada perlakuan control (tanpa perlakuan abu sekam padi), pengaruhnya berbeda nyata dengan perlakuan lainnya. Sebaliknya kadar air minyak kopra terendah $(0,10 \%)$ pada perlakuan abu sekam padi konsentrasi 20 dam 25, pengaruhnya tidak
e-ISSN : 2621-6973

p-ISSN : 2527-5631

berbeda nyata dengan perlakuan abu sekam padi konsentrasi $15 \%$, tetapi nyata berbeda dengan perlakuan lainnya. Hasil ini member petunjuk bahwa konsentrasi abu sekam padi 15, 20 dan $25 \%$ memberikan pengaruh yang sama terhadap kadar air minyak kopra.

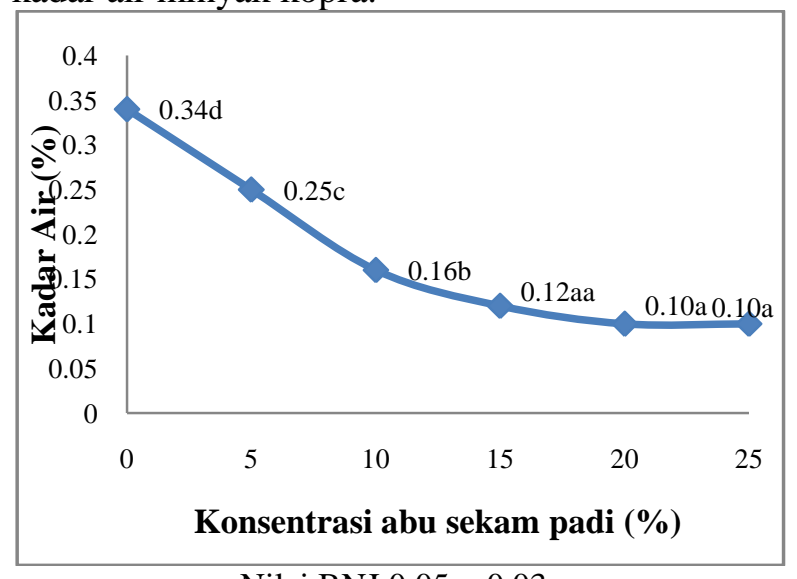

Gambar 3. Kadar air minyak kopra pada berbagai konsentrasi abu sekam padi

Berdasarkan data pada Gambar 3 dapat dilihat bahwa semakin banyak ditambahkan abu sekam padi maka semakin menurun pula kadar air minyak kopra yang dihasilkan. Kemampuan abu sekam padi sebagai adsorben dalam menyerap air sejalan dengan hasil penelitian Fokkink (1987), yang melaporkan bahwa abu sekam padi mengandung silika dan selulosa, dimana kedua senyawa tersebut mempunyai gugus hidroksil permukaan yang dapat memberikan kontribusi terhadap penyerapan air dalam minyak kopra

Kadar air minyak kopra hasil perlakuan abu sekam padi konsentrasi 25 - 5\% berkisar antara $0,10-0,25 \%$. Angka ini sudah memenuhi syarat SII yang dipersyaratkan maksimal $0,30 \%$. Hal ini diduga bahwa bahan baku kopra yang dipres memenuhi kualitas kadar air kopra maksimal 6 persen (Muchtadi, dkk., 2015). Kualitas minyak ditentukan oleh 3 (tiga) faktor yaitu; bahan baku, peralatan dan proses pengolahan (Jalil, 2013).

\section{Kadar Asam Lemak Bebas (\%)}

Analisis ragam menunjukkan bahwa penggunaan abu sekam padi berpengaruh sangat nyata terhadap kadar asam lemak bebas minyak kopra. Nilai rata kadar asam lemak bebas minyak kopra disajikan pada Gambar 4. 


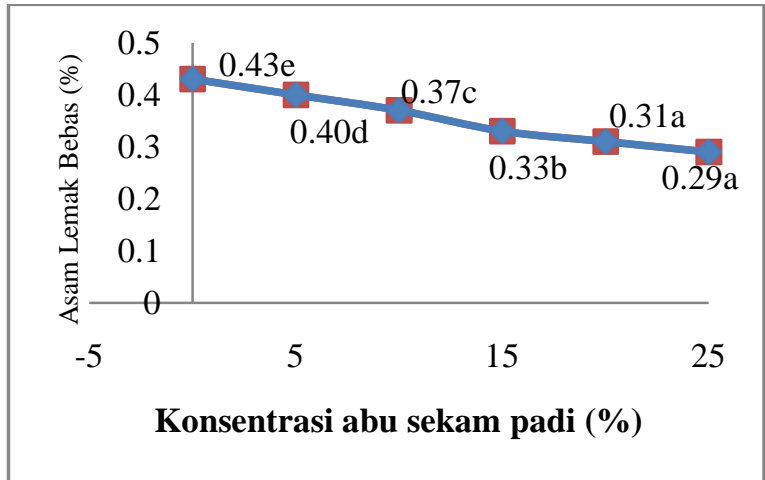

Gambar 4. Kadar asam lemak bebas minyak kopra pada berbagai konsentrasi abu sekam padi

Data yang tersaji pada Gambar 4 menunjukkan bahwa kadar asam lemak bebas minyak kopra tertinggi $(0,43 \%)$ ditemukan pada perlakuan kontrol (tanpa perlakuan abu sekam padi), pengaruhnya berbeda nyata dengan perlakuan lainnya. Sebaliknya kadar asam lemak bebas minyak kopra terendah $(0,29 \%)$ pada perlakuan abu sekam padi konsentrasi 25\%, pengaruhnya tidak berbeda nyata dengan perlakuan abu sekam padi konsentrasi 20\%, tetapi nyata berbeda dengan perlakuan lainnya. Hasil ini memberi petunjuk bahwa konsentrasi abu sekam padi 20 dan $25 \%$ memberikan pengaruh yang sama terhadap kadar asam lemak bebas minyak kopra.

Kadar asam lemak bebas merupakan salah satu syarat penentuan kualitas minyak, apabila kadar asam lemak bebas minyak konsumsi melebihi dari syarat maksimal, maka minyak tersebut tidak layak konsumsi. Asam lemak bebas disebabkan terjadinya proses oksidasi dan kerja enzim lipase dalam bahan minyak. Berdasarkan data pada Gambar 4 memberi petunjukbahwa kadar asam lemak bebas minyak kopra menurun dengan semakin tingginya perlakuan konsentrasi abu sekam padi.

Sekam padi adalah suatu sumber silika biologi yang umumnya banyak terdapat di negara berkembang dan mempunyai adsorben pigmen yang potensial dalam pengolahan minyak (Proctor et al., 1995). Abu sekam padi telah diuji sebagai adsorben alternatif dalam pengolahan minyak. Abu sekam mengandung gugus hidoksi yang bermuatan ion negatif sehingga dapat menarik kation-kation yang bermuatan positif (Fokkink, 1987).

Proctor, Tan and Palaniappan (1992) melaporkan bahwa adsorbsi fosfolifida ke dalam abu sekam padi dengan dosis yang lebih kecil adalah lebih efisien daripada dosis yang besar.
Sebagian besar pigmen yang hilang dari minyak adalah xanthopyll lutein. Residu asam lemak bebas, fosfolipida dan hasil oksidasi peroksida yang masih ada setelah pemurnian dan penghilangan gum juga terserap oleh adsorben abu sekam padi, silika hidrogel, silika sekam padi, dan bleaching cley (Proctor et al., 1995). Studi difraksi sinar X menunjukkan bahwa abu sekam padi adalah suatu silika amorfous dalam bentuk Opal CT (Proctor et al., 1995). Analisa menggunakan alat spektroskopi inframerah menunjukkan silika amorfous ini dapat menyerap secara alami FFA dan fosfo lipida serta lutein dari misella minyak pada suhu kamar (Istinigrum, $d k k ., 2017)$.

\section{Derajat Kejernihan (\% T)}

Analisis ragam menunjukkan bahwa penggunaan abu sekam berpengaruh sangat nyata terhadap derajat kejernihan minyak kopra. Nilai rata derajat kejernihan minyak kopra disajikan pada Gambar 5.

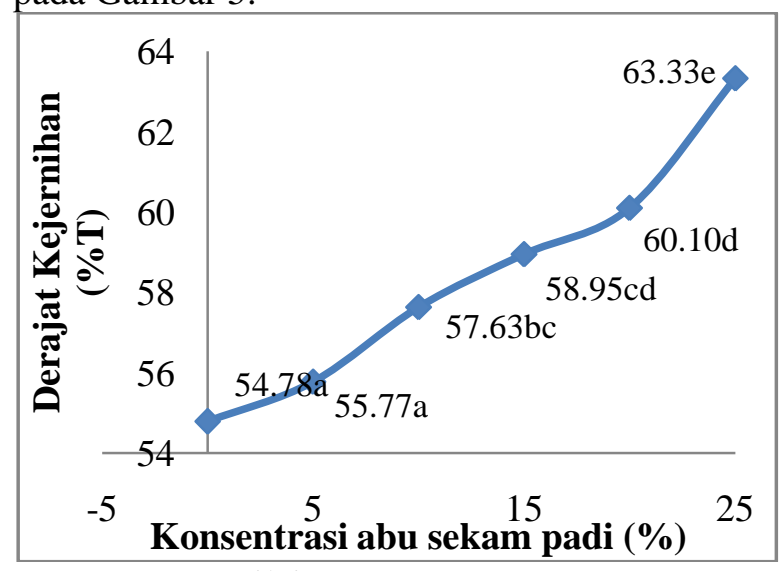

Nilai BNJ 0,05 $=1,54$

Gambar 5. Derajat kejenihan minyak kopra pada berbagai konsentrasi abu sekam padi

Data yang tersaji pada Gambar 5 menunjukkan bahwa derajat kejernihan minyak kopra terendah $(54,78 \%)$ ditemukan pada perlakuan kontrol (tanpa perlakuan abu sekam padi), pengaruhnya berbeda nyata dengan perlakuan lainnya. Sebaliknya derajat kejernihan minyak kopra tertinggi $(63,33 \%)$ terdapat perlakuan abu sekam padi konsentrasi $25 \%$, pengaruhnya berbeda nyata dengan perlakuanlannya. Hasil ini memberi petunjuk bahwa masing perlakuan yang dicobakan dalam penelitian ini memberikan pengaruh yang nyata berbeda terhadap derajat kejernihan minyak kopra. Berdasarkan data pada Gambar 5 bahwa semakin banyak jumlah abu sekam padi yang digunakan semakin tinggi derajat kejernihan dari 
minyak kopra yang dihasilkan. Hal ini diduga karena semakin banyak dan tebal abu sekam semakin banyak kotoran yang tersaring oleh abu sekam padi yang digunakan.

Tingginya derajat kejernihan pada pemberian abu sekam padi pada konsentrasi $25 \%$ disebabkan oleh daya adsorbsi abu sekam padi yang mempunyai pori-pori dalam jumlah besar (luas permukaan) dimana adsorbsi terjadi karena adanya perbedaan energi potensial antara permukaan abu sekam padi dengan minyak kopra. Menurut Ketaren (1986), efisiensi adsorbsi oleh arang tergantung dari perbedaan muatan listrik antara arang dengan zat atau ion yang diserap. Mekanisme arang tersebut tidak jauh berbeda dengan abu sekam padi yang keduanya merupakan adsorben aktif. Minyak yang mempunyai muatan listrik positif akan diserap lebih efektif oleh abu sekam padi dalam larutan yang bersifat basa dan sebaliknya, sedangkan penyerapan terhadap bahan non elektrolik tidak dipengaruhi oleh keasaman atau sifat kebasaan abu sekam padi sebagai adsorben. Dengan demikian konsentrasi abu sekam padi yang digunakan dimana makin tinggi konsentrasi maka makin tinggi pula derajat kejernihan yang dihasilkan sehingga konsentrasi berpengaruh terhadap jumlah warna yang diserap. Warna coklat pada minyak kelapa yang mengandung protein dan karbohidrat sebenarnya bukan disebabkan oleh zat warna alamiah tetapi oleh reaksi browning, dimana warna ini merupakan hasil reaksi dari senyawa karbonil (yang berasal dari pemecahan peroksida) dengan asam amino dan protein yang terjadi terutama pada suhu tinggi. Sehingga dengan pemberian abu sekam padi dapat memperbaiki mutu minyak kelapa tradisional.

Pengolahan minyak dari bahan baku kopra pada umumnya dengan cara kering adalah mengepres/mengempa kopra, menghasilkan minyak dengan kejernihan yang kurang dan protein terdenaturasi. Proses kering menggunakan bahan baku yang telah melalui proses pengurangan air seperti pengeringan, contohnya adalah bahan baku kopra (Jalil, 2013).

\section{Kesimpulan dan Saran}

\section{Kesimpulan}

a). Perlakuan konsentrasi abu sekam padi memberikan pengaruh yang sangat nyata terhadap recovery, kadar air, kadar asam lemak bebas dan derajat kejernihan minyak kopra. b). Perlakuan konsentrasi abu sekam padi konsentrasi $20 \%$ memberikan pengaruh yang lebih baik terhadap kualitas minyak kopra.

\section{Saran}

Perlu dilakukan penelitian lanjut tentang peningkatan daya abu sekam padi dan aplikasinya dalam pengolahan minyak kopra.

\section{Daftar Pustaka}

Andersen, A.J.C., 1958. Refining Oils and Fats for Edible Purpose. Pergamon Press Ltd, London.

Apriyantono, A., D. Ferdiaz., N.L. Puspitasari., Sedarnawatidan S. Budiyanto, 1989. Analisis Pangan. PAU Pangan dan Gizi Institut Pertanian Bogor.

Fokkink, L.G.J., 1987. Ion Adsorpsion on Oxides. Tesis, Wageninge Nederland.

Gomez, K.A and A.A.Gomez, 1995. Statistical Procedures for Agricultural Research. John Wiley \& Sons, Inc, Filiphine.

Grimwood, 1975. 'Coconut Palm Products. The Processing ini Developing Countries'. FAO Agricultural Development Paper No. 9 Tropical Product Institute. London

Jalil, 2013. Teknologi Lemak dan Minyak. Penebar Swadaya. Jakarta.

Karmawati, Luntungan H., Hobir, Sudarisma, Endang S., dan Budiharto A. 1992. Perbaikan Pengolahan Minyak Klentik. Badan Penelitian dan Pengembangan Tanaman Industri. Bogor.

Ketaren., 1986. Minyak dan Lemak Pangan. Universitas Indonesia. Jakarta.

Muchtadi, T.R., 1998. Tinjauan Umum Minyak Goreng Asal Kelapa. Makalah pada Pelatihan Singkat Teknologi Sederhana Pengolahan Minyak Kelapa, Bogor, 29 - 30 Agustus 1998.

Proctor, A., C. Adhikari, and G.D. Blyholder, 1995 . Mode of Oleic Acid Adsorption on Rice, Hull Ash Cristobalite. JAOCS, vol. 72, (3) : $331-335$.

Proctor, A., P.K. Clark and C.A. Parker, $1995^{\mathrm{b}}$. Rice Hull Ash Performance Under Commercial Soy Oil Bleaching Conditions. JAOCS, vol. 72, (4) : 459 - 462.

Proctor, A., L.C. Tan., and S. Palaniappan, 2002. Phospholipid Adsorption onto Rica 
HullAsh Cristobalite. JAOCS, vol. 69, (10) : 1049 - 1050.

Sadikin, Y.T., 1992. Pengaruh Lama Penggorengan dan Penggunaan Absorben Terhadap Mutu Minyak Goreng Bekas Penggorengan Tahu-Tempe. Skripsi FATEMETA, IPB, Bogor.

Sudarmadji, S., B. Haryono, dan Suhardi, 1996. Analisa Bahan Makanan dan Pertanian, Liberty, Yogyakarta.
Setyaningtyas, Tien, Zusfahair, dan Suyata, 2005. Majalah Kimia: Pemanfaatan Abu Sekam Padi Sebagai Adsorben Kadmium (II) dalam Pelarut Air, Vol.2005, 31(1), 33-41.

Widiandani, T. Purwanto, T. Hardjono, S. Tri, B.P.Susilowati, R.dan Diyah , N.W., 2010. Upaya Peningkatan Kualitas Minyak Kelapa Yang Dibuat Dari Cocos Nucifera L Dengan Berbagai Metode Kimiawi Dan Fisik. Departemen Kimia Farmasi. Fakultas Farmasi Universitas Airlangga. Surabaya. 